\title{
Response of Eichhornia crassipes (Pontederiaceae) to water level fluctuations in two lakes with different connectivity in the Paraná River floodplain
}

\author{
Juan José Neiff ${ }^{1}$, Sylvina Lorena Casco $^{2} \&$ Alicia Poi de Neiff ${ }^{1,2}$ \\ 1. Consejo Nacional de Investigaciones Científicas y Técnicas, Centro de Ecología Aplicada del Litoral, C.C. 291, \\ Corrientes, Argentina. Fax: 0054-3783-454421; jj@neiff.com.ar \\ 2. Universidad Nacional del Nordeste, Departamento de Biología, Corrientes, Argentina.
}

\author{
Received 26-II-2007. C Corrected 13-IX-2007. Accepted 14-III-2008.
}

\begin{abstract}
Floodplain lakes are especially dynamic due to the irregular flow regime of the Paraná River and its location along the geomorphologic gradient between the lakes and the river. The response of Eichhornia crassipes (Mart.) Solms (one of the most frequent aquatic plant) was studied in two floodplain lakes with different flooding regimes. Samples were taken between March 1997 and December 2001 on 13 different hydrologic conditions during prolonged hydrologic connection and prolonged hydrologic isolation. Leaf height, leaf density, biomass and nutrient content of the mature leaves of E. crassipes were measured and related to water level fluctuation and the hydrologic connectivity. The lake more connected with the main channel had a long lasting inundation phase. In this condition the surface area covered by water increased more than three times compared to prolonged hydrologic isolation condition. As river water entered the floodplain lakes, dissolved inorganic nitrogen increased to high values, especially $\mathrm{NO}_{3}^{-}$, whereas the isolation condition was characterised by a decrease in $\mathrm{NO}_{3}{ }^{-}$concentrations to undetectable levels. Compared to plants growing in the more isolated lake, those growing in the more connected lake had a significantly lower leaf density, longer leaves, less root biomass and lower ratio between below-ground and above-ground biomasses. However, total and leaf biomasses were not significantly different between sites. In each lake, differences in leaf height, leaf biomass and root biomass between prolonged hydrologic connection and isolation, as well as the insignificant relationship between leaf size and leaf density, indicate that the morphological traits of E. crassipes respond to pluri-annual water level fluctuations. The highest nutrient concentration in mature leaves was registered at the end of the prolonged hydrologic connection in the more connected lake. During the prolonged isolation, leaves had more lignin and a higher L:N ratio than at high waters, at the same sites. The success of E. crassipes in occupying habitats subjected to wide and erratic fluctuations in water level, such as the Paraná River floodplain, appears to be related to its ability to modify morphological traits according to water level. Rev. Biol. Trop. 56 (2): 613-623. Epub 2008 June 30.
\end{abstract}

Key words: large rivers, Eichhornia crassipes, river pulses, floodplain lakes.

The floating meadows of Eichhornia crassipes (Mart.) Solms. are frequent in large rivers of South America (Puhakka and Kalliola 1993, Colonello 1995, Navarro and Maldonado 2002) because the plant is successful in the occupation of lakes subjected to fluctuation in water level (Neiff 1986, Neiff et al. 2001). The morphological trait of the plant varied in different river basins (Da Silva and Esteves 1993, Blanco et al. 1998, Rodriguez and Betancourt 1999) and the temporal variations in biomass has been related to changes in the water level (Da Silva and Esteves 1993).

The flow regime of the Paraná River is irregular compared to other large South American Rivers (Neiff 1996, Thomaz et al. 2004), with floods of different intensity, recurrence and amplitude. Thus, in alluvial floodplain lakes, large morphological and biotic spatial gradients are observed in relation to its topographic position respect to the overflow level (Neiff 2001) that determine different 
frequency and timing of connection to the river course and different exchange of nutrients. The abundance of E. crassipes, which is invasive in other subtropical waters (Ashton 1973), constitutes the principal characteristic distinguishing the floodplain downstream from the confluence with the Paraguay River. In lakes isolated from the river, biomass increases from August to March and declines to about $50 \%$ of its annual maximum during winter (Neiff and Poi de Neiff 1984). This seasonal pattern growth in tropical and subtropical waterbodies (Sahai and Sinha 1970, Center and Spencer 1981, Da Silva and Esteves 1993, Wilson et al. 2005), with reduction of biomass in winter, make difficult to identify the effect of water level during an only annual cycle. In addition, plant density affect plant height (thus biomass), especially during the spatial spread of E. crassipes in areas previously free of vegetation.

The fertilization pattern observed in the floodplain of the Paraná River indicated that the inflow of dissolved inorganic nitrogen during flood of short duration does not appear to stimulate E. crassipes growth (Carignan and Neiff 1992) and that prolonged flooding condition was characterized by increases in the mean leaf maximum size (Neiff et al. 2001).

This study was designed to examine leaf height, leaf density, biomass, nutrient content of the mature leaves, and the ratio between below-ground and above-ground biomasses in two floodplain lakes with different degree of connectivity under different hydrologic condition to answer the following questions. Firstly, does the flooding regime of different floodplain lakes influence the morphological trait of the $E$. crassipes and its nutrients content? Secondly, increase in biomass during prolonged hydrologic connection of both lakes are related to increase in leaf height or increase in leaf density?

\section{MATERIALS AND METHODS}

Study site: the study area is located within the RAMSAR Site CHACO (Argentina) on the west bank of the Paraná River, $30 \mathrm{~km}$ downstream from its confluence with the Paraguay
River. On this margin, several oxbow lakes separated by alluvial levees are located in the floodplain 0.5 to $5 \mathrm{~km}$ from the main channel. We selected two sites where E. crassipes was found in monospecific stands that covered up to $70 \%$ of the water surface of both floodplain lakes. Plants of water hyacinth with elongate leaves (large biotype), which occurs in dense mats, were dominant. The short inflated petiole (small biotype), which occurs in more open conditions, was exceptionally found during the study period. Water is the main source of nutrients for this free floating plant which remains in the floodplain lakes during high and low water phases. Changes in the water level affect the plants located in the margin which die during extreme floods or prolonged drought.

San Nicolás lake (Site A, $27^{\circ} 27^{\prime}$ S; $58^{\circ} 55^{\prime}$ W) is connected with the Paraná River from one to three times per year, when the water level at the Corrientes datum exceeds $4.85 \mathrm{~m}$. El Puente lake (Site B, $26^{\circ} 26^{\prime} \mathrm{S}$; $58^{\circ} 51^{\prime} \mathrm{W}$ ) is more frequently inundated with long-lasting floods.

The number of flooding days (potamophase) and the number of isolated days (limnophase) were calculated with the Software PULSE (Neiff and Neiff 2003). The elasticity (Neiff et al. 1994) was calculated for each lake, as the quotient between the maximum area during the prolonged flooding (Site $\mathrm{A}=14.52$ ha and Site $\mathrm{B}=23.40 \mathrm{ha})$ and the minimum area occupied after the prolonged drought (Site $A=3.77$ ha, Site $B=7.31$ ha) using LANDSAT 7 TM scenes of May 4, 1998 and January 4, 2001, respectively.

The Fluvial Connectivity Quotient (Neiff and Poi de Neiff 2003) was calculated for the period 1997-2001 as follows:

$$
\text { FCQ }=\frac{\text { number of flooded days }}{\text { number of isolated days }}
$$

Sampling design: between March 1997 and December 2001, three replicate samples were taken three meters off the margin on 13 different hydrologic conditions during 
prolonged connection and prolonged isolation. Our sampling unit consisted of a $0.3058 \mathrm{~m}^{2}$ aluminium ring (62.4 $\mathrm{cm}$ diameter). We used this sampler type because in a previous trial circular delimiters yielded smaller standard deviations (mean leaf density $=413, \mathrm{SD}=10.12$, $\mathrm{n}=10$ ) than square delimiters (mean leaf density $=410, \mathrm{SD}=18.80, \mathrm{n}=10)$ of the same area (3 $000 \mathrm{~cm}^{2}$ ). When we compared ten replicates samples taken with circles of 1000,3000 and 5000 , the coefficients of variation were 22.1, 10.99 and $7 \%$ respectively. Thus, a $3000 \mathrm{~cm}^{2}$ circular sampler reduced the sampling effort with a level of precision near $11 \%$. According to Downing and Anderson (1985), three replicate samples were needed for $3000 \mathrm{~cm}^{2} \mathrm{sam}$ pler size and levels of macrophyte biomass more than $320 \mathrm{~g}$ dry weight per $\mathrm{m}^{2}$. In addition, between 3 and 5 samples of $0.25 \mathrm{~m}^{2}$ were suggested to estimate macrophyte biomass in tropical studies (Pompêo and Moschini-Carlos 2003). All green and standing dead leaves were cut off, separated and counted. Density estimates referred to the number of leaves and not to the number of plants, due to the high variability in the number of leaves of each plant. New leaves less than $10 \mathrm{~cm}$ sheathed around old leaves were not included in these estimations because they do not occupy significant space within the stand. The height of 7659 green leaves was measured from the base of the petiole up to the end of the blade at high (3 105) and low water (4 554) phases. On each sampling date, the weight of green leaves and roots were measured after drying at $105{ }^{\circ} \mathrm{C}$.

Differences in average leaf density, leaf height, leaf biomass, root biomass and the ratio between below-ground and above-ground biomasses $(n=13)$ between floodplain lakes were tested using the paired-samples t-test. At each site, comparisons of leaf and root biomasses between hydrological phases were made with the Wilcoxon test. Regression analysis was used to test the relationship between leaf density and leaf height. All variables were log transformed to normalize distributions. Differences were considered significant at $\mathrm{p}<0.05$, using the software InfoStat version 1.1. (2002) for these analysis.

Air temperature was recorded with a LiCor (LI-1200S) data logger. Integrated water column samples $(1 \mathrm{~L})$ were collected within the floating meadows. Water samples were filtered within 1-2 $\mathrm{h}$ of collection on pre-washed Gelman DM-450 $(0.45 \mu \mathrm{m})$ membranes for spectrophotometric analyses of $\mathrm{NH}_{4}^{+}$(indophenol blue method), $\mathrm{NO}_{3}^{-}+\mathrm{NO}_{2}^{-}$(henceforth called $\mathrm{NO}^{-3}$ ) by reduction on $\mathrm{Cd}$ and total phosphorus (molybdenum blue method) after persulfate oxidation (APHA 1999). On the same occasions, 10 green mature leaves from each plot were dried at $60{ }^{\circ} \mathrm{C}$ to determine nutrient content. Nitrogen (macro Kjeldähl method), phosphorus (AOAC 1990) and fiber content (Ankom Fiber Analyzer) were expressed as the $\%$ dry weight.

\section{RESULTS}

During the sampling period, maximum air temperature (Fig. 1) reached $41.6^{\circ} \mathrm{C}$ in January 2000 and there were high values in the spring (up to $35^{\circ} \mathrm{C}$ ). The lowest minimum temperature $\left(-3.3^{\circ} \mathrm{C}\right)$ was recorded in unusually cold winters (June 1999 and 2000).

By October 1996, river water was entering the northern zone of Site B by diffuse connections with neighbouring swamp through the Tragadero Stream (affluent of the Paraná River). Between January 1997 and December 2001, Site A was connected with the main channel during 544 days (16 pulses), whereas Site B was flooded 689 days (11 pulses, Fig. 2). The number of isolated days was 973 and 763 days respectively. The Fluvial Connectivity Quotient was lower at Site A (0.56) than at Site B (0.90). According to location along the geomorphologic gradient, each floodplain lake has different elasticity quotient (Site $\mathrm{A}=3.85$, Site $B=3.2$ ). In relation to water level fluctuations of Paraná River, the depth of the lakes varied between $1.62 \mathrm{~m}$ and $5.20 \mathrm{~m}$ (Site B), and between 0.75 and $3.80 \mathrm{~m}$ (Site A).

Water temperature measured at 10:00 AM ranged from $11{ }^{\circ} \mathrm{C}$ to $27.2{ }^{\circ} \mathrm{C}$ (Table 1). 


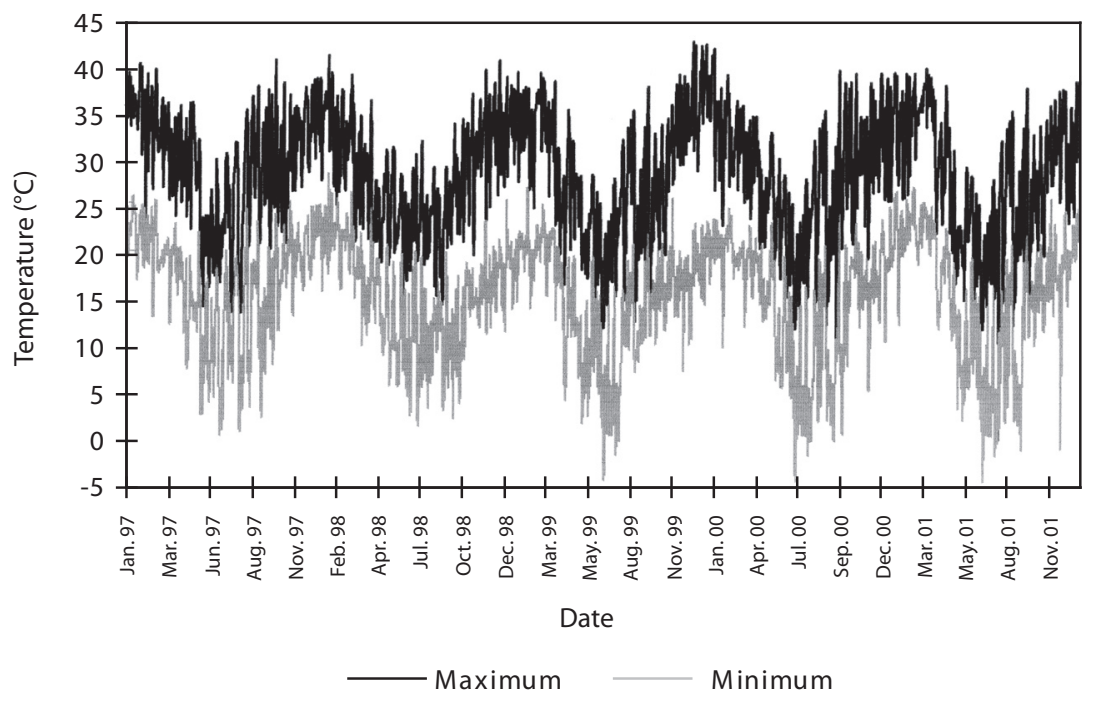

Fig. 1. Daily variations of air temperature at the study area.

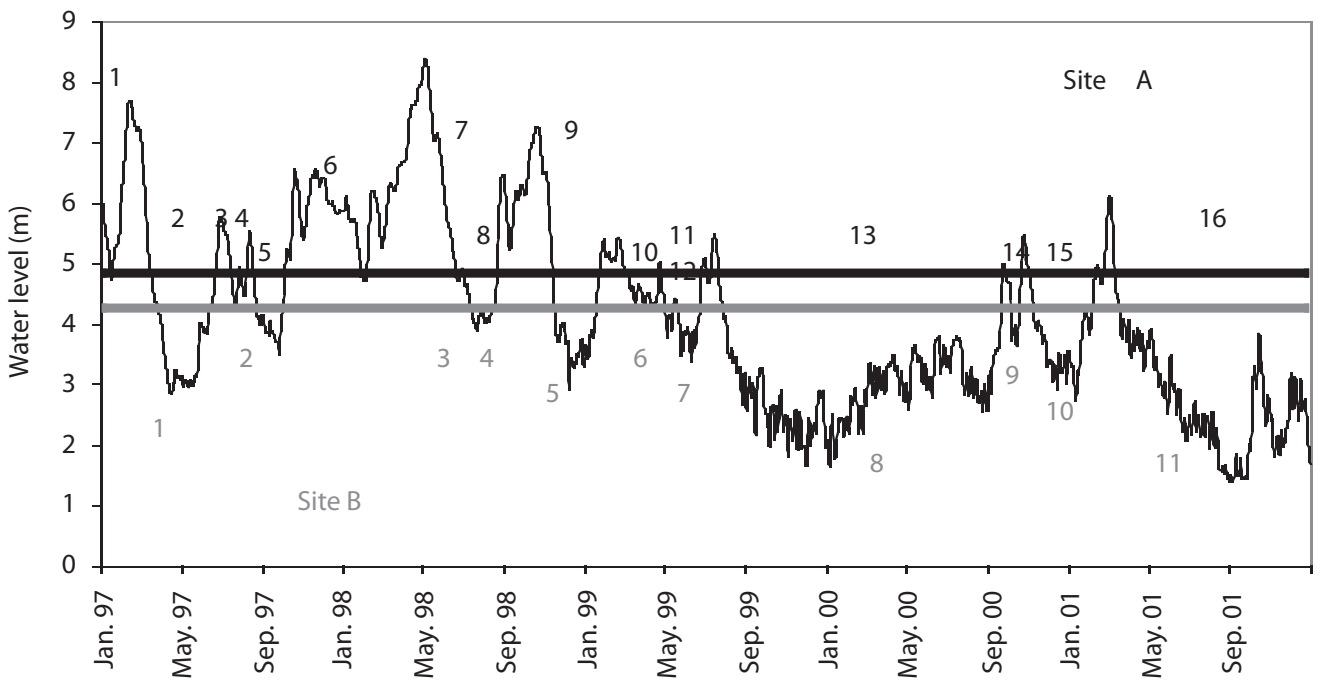

Fig. 2. Water level fluctuations of the Paraná River at Corrientes between 1997 and 2001. The sites were connected with the Paraná above the hydrological level indicated by the horizontal lines. Numbers indicate the number of pulses in each lake.

Dissolved oxygen content was higher and conductivity was in general lower during prolonged hydrologic connection compared to the prolonged hydrologic isolation.

As river water entered the floodplain lakes, dissolved inorganic nitrogen increased to high values, especially $\mathrm{NO}_{3}$ (Table 1). At high water, phosphate concentrations varied between 50 and $105 \mu \mathrm{g} \mathrm{l}^{-1}$ and showed little change during and after the flood. There was a decreased in $\mathrm{PO}_{4}-\mathrm{P}$ at the end of the growth period during the prolonged low water condition. The $\mathrm{pH}$ ranged from 6.9 to a maximum of 7.9 (Table 1), which coincided with Paraná-Paraguay 
TABLE 1

Physical and chemical variables at both sites during different hydrologic conditions

SITE A

Water conditions

Temperature $\left({ }^{\circ} \mathrm{C}\right)$

Transparency $(\mathrm{cm})$

Conductivity $\left(\mu \mathrm{S} . \mathrm{cm}^{-1}\right)$

Dissolved oxygen (mg..$\left.^{-1}\right)$

$\mathrm{pH}$

$\mathrm{NO}_{3}-\mathrm{N}\left(\mu \mathrm{g} \cdot \mathrm{l}^{-1}\right)$

$\mathrm{NH}_{4}-\mathrm{N}\left(\mu \mathrm{g} .1^{-1}\right)$

$\mathrm{PO}_{4}-\mathrm{P}\left(\mu \mathrm{g} \cdot \mathrm{l}^{-1}\right)$

SITE B

Water conditions

Temperature $\left({ }^{\circ} \mathrm{C}\right)$

Transparency $(\mathrm{cm})$

Conductivity $\left(\mu \mathrm{S} . c m^{-1}\right)$

Dissolved oxygen (mg..$\left.^{-1}\right)$

$\mathrm{pH}$

$\mathrm{NO}_{3}-\mathrm{N}\left(\mu \mathrm{g} \cdot \mathrm{l}^{-1}\right)$

$\mathrm{NH}_{4}-\mathrm{N}\left(\mu \mathrm{g} .1^{-1}\right)$

$\mathrm{PO}_{4}-\mathrm{P}\left(\mu \mathrm{g} \cdot .^{-1}\right)$
Prolonged hydrologic connection

1997

Oct Dec Mar May Aug Oct Dec Mar Apr May Jul Dec

$\begin{array}{llllllllllll}24 & 24.5 & 21 & 18 & 16.5 & 23 & 23 & 24 & 24 & 17.5 & 11 & 26.5\end{array}$

$\begin{array}{llllllllllll}71 & 66 & 43 & 56 & 67 & 62 & 21 & 19 & 39 & 34 & 42 & 42\end{array}$

$\begin{array}{llllllllllll}110 & 100 & 80 & 90 & 210 & 255 & 295 & 260 & 220 & 180 & 225 & 240\end{array}$

$\begin{array}{llllllllllll}2.1 & 3.7 & 3.5 & 4 & 5 & 2.4 & 2.7 & 2.5 & 0.5 & 1.2 & 1.2 & 1.9\end{array}$

$\begin{array}{llllllllllll}6.9 & 6.9 & 7.9 & 7.5 & 7.8 & 6.6 & 6.3 & 7 & 6.5 & 6.5 & 6.3 & 6.1\end{array}$

$\begin{array}{lllllllllll}10 & 330 & 125 & 50 & 65 & \text { bdl } & \text { bdl } & \text { bdl } 10 & \text { bdl } & \text { bdl } & \text { bdl }\end{array}$

$\begin{array}{llllllllllll}50 & 100 & 20 & \text { bdl } & 60 & 75 & 70 & 40 & 100 & 130 & 130 & 70\end{array}$

$\begin{array}{llllllllllll}55 & 82 & 67 & 99.8 & 93 & 35 & 10 & 5 & 220 & 71 & 100 & 10\end{array}$

Prolonged hydrologic connection

Prolonged hydrologic isolation

$\begin{array}{lllll}1997 & 1998 & 1999 & 2000 & 2001\end{array}$

$\begin{array}{cccccccccccc}\text { Oct } & \text { Dec } & \text { Mar } & \text { May } & \text { Aug } & \text { Oct } & \text { Dec } & \text { Mar } & \text { Apr } & \text { May } & \text { Jul } & \text { Dec } \\ 24.5 & 24.5 & 22 & 19 & 16 & 22.5 & 24 & 24.8 & 17 & 16.5 & 13 & 27.2 \\ 73 & 77 & 47 & 61 & 51 & 65 & 40 & 26 & 30 & & 45 & 46 \\ 120 & 100 & 110 & 90 & 115 & 260 & 300 & 200 & 190 & 190 & 260 & 280 \\ 2.1 & 4.9 & 4.7 & 4.9 & 5.3 & 2.6 & 1.2 & 0.5 & 1.2 & 1.5 & 1.7 & 1.3 \\ 7.0 & 7.0 & 7.6 & 7.3 & 7.9 & 6.5 & 6.3 & 6.7 & 6.5 & 7 & 6.5 & 6.3 \\ 5 & 315 & 145 & 60 & 110 & 55 & \text { bdl } & \text { bdl } & \text { bdl } & \text { bdl } & 20 & \text { bdl } \\ 45 & 65 & 5 & 5 & 85 & 75 & 60 & 60 & 100 & 40 & 120 & 60 \\ 50 & 86 & 80 & 92.5 & 105 & 70 & 5 & 10 & 105 & 74 & 70 & 5\end{array}$

bdl: below detection limit.

river water entering the floodplain lakes. The isolation phase of lakes was characterized by an immediate decrease in dissolved inorganic $\mathrm{NO}^{-}$concentrations to undetectable levels. During the prolonged hydrologic isolation the $\mathrm{pH}$ remained slightly acid and $\mathrm{NH}_{4}-\mathrm{N}$ concentration in the water increased.

Comparison between sites revealed that $E$. crassipes floating meadows occurring in the lake less connected were significantly more dense $(t=2.25, p<0.04)$ than those occurring in the more connected lake. Conversely, plants growing in the more connected lake had significantly longer leaves $(t=2.77, p<0.017)$ than those of the Site A. Total biomass ( $\mathrm{t}=0.71$, $\mathrm{p}>0.4886)$ and leaf biomass $(\mathrm{t}=1.18, \mathrm{p}>0.2591)$ were not significant different between sites (Table 2). The ratio between below-ground and above-ground biomasses ranged from 0.19 to 1.57 (Site A) and from 0.13 to 1.10 (Site B). Given that there was significantly more root biomass $(\mathrm{t}=3.32, \mathrm{p}<0.0061)$ at Site $\mathrm{A}$, the differences in the ratio between below-ground and above-ground biomasses between lakes were significant $(\mathrm{t}=2.54, \mathrm{p}<0.02)$.

At both sites, according to the Wilcoxon test, there was significantly more leaf biomass (Site $A=266, p<0.013$; Site $B=250, p<0.0031$ ) and 


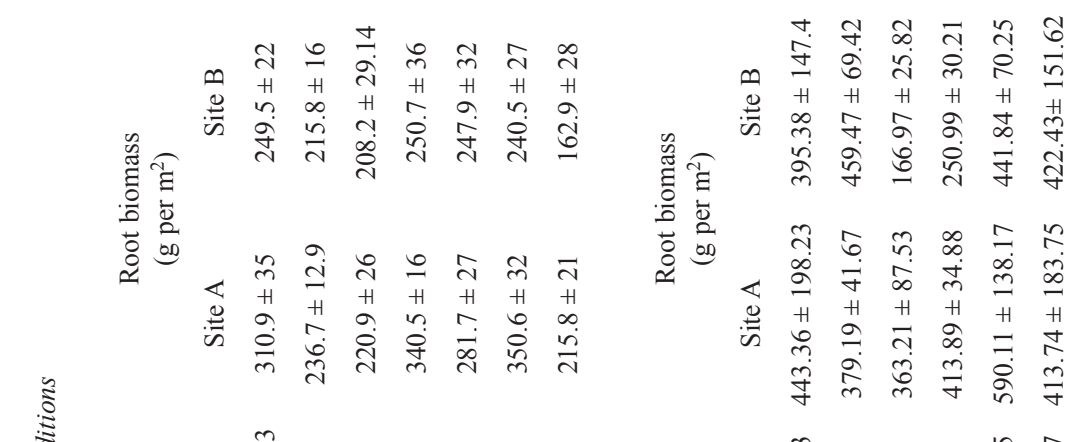

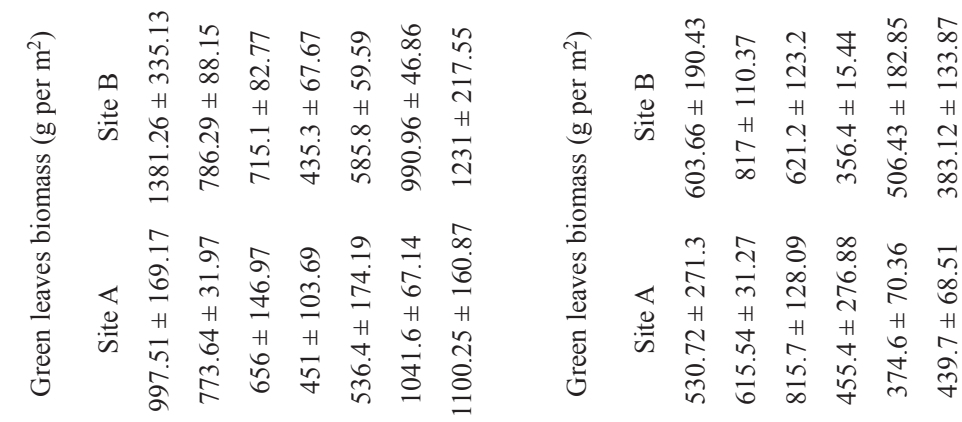

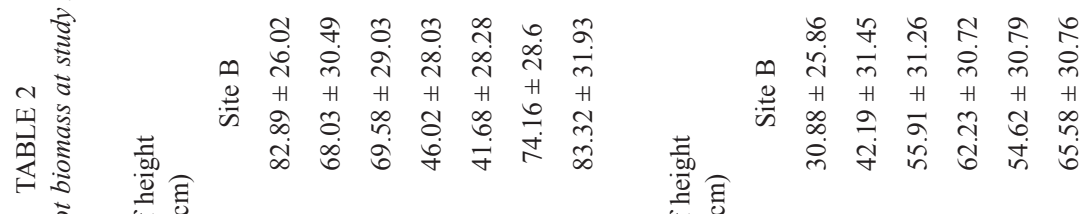

$$
\begin{aligned}
& \text { 望 }
\end{aligned}
$$

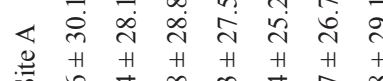

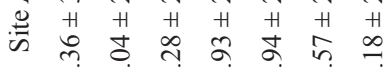

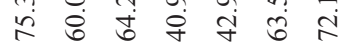

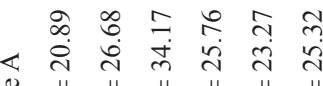

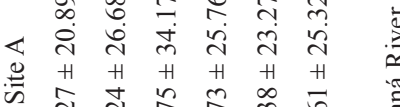

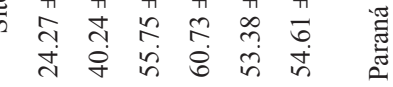

$$
\begin{aligned}
& \text { ๗ँ }
\end{aligned}
$$

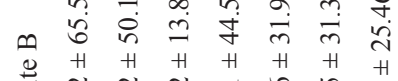

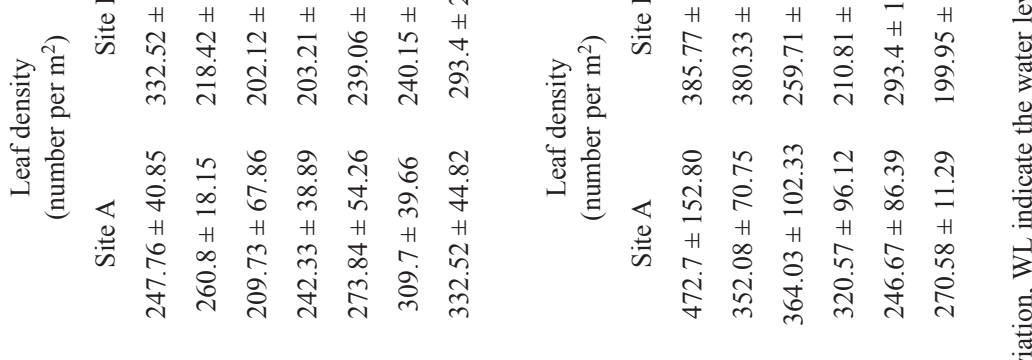

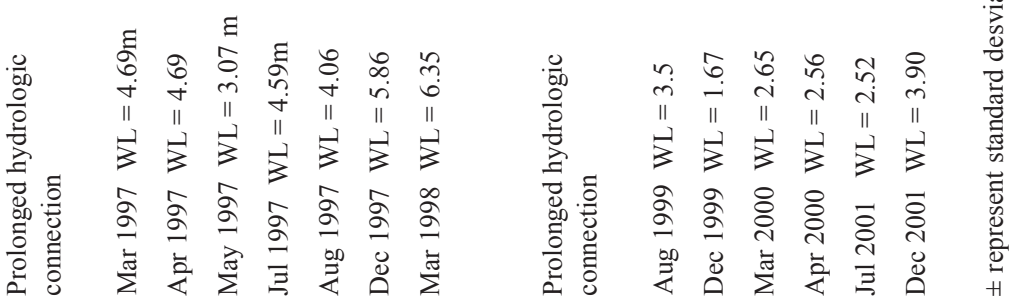


less root biomass (Site $A=327, p>0.0004$; Site $\mathrm{B}=330, \mathrm{p}<0.0005$ ) during the prolonged hydrologic connection than the prolonged hydrologic isolation. Although differences in leaf density between these hydrologic conditions were significant at Site $\mathrm{A}\left(\mathrm{W}_{20,18}=439, \mathrm{p}<0.03\right)$ and not significant at Site $B\left(\mathrm{~W}_{20,18}=357, \mathrm{p}=0.64\right)$, there was no significant relationship between leaf density and leaf height at Site $\mathrm{A}\left(\mathrm{r}^{2}=0.01\right.$, $\mathrm{p}>0.4798)$ and $\mathrm{B}\left(\mathrm{r}^{2}=0.04, \mathrm{p}>0.2179\right)$.

In both lakes, the ratio between belowground and above-ground biomasses was lower at the prolonged hydrologic connection than at the prolonged hydrologic isolation. Maximum biomass was registered at Site B during March 1997, whereas a maximum leaf length of 118.5 $\mathrm{cm}$ was measured at the end of the prolonged flood (March 1998).

After the first pulse (March 1997) both lakes had high frequency of leaves more than $90 \mathrm{~cm}$. Floods occurred in winter do not appear to stimulate leaf growth due to the low temperature registered in the study area. Thus during August 1997, the relative frequency of leaves between 0 and $90 \mathrm{~cm}$ was less than $40 \%$ and the leaves more than $90 \mathrm{~cm}$ were infrequent (Fig. 3 ). This was due to the senescence of the larger leaves and the subsequent replacement by plants of the new growth. At December 1997 (during the pulse 3) there was an increase of frequency of leaves which size ranged between 71 and $90 \mathrm{~cm}$ at Site A, and the ones more than $90 \mathrm{~cm}$ at Site B. This took place again more clearly in March 1998 when the river reached $6.35 \mathrm{~m}$ in the Corrientes gauge. During the prolonged hydrologic isolation (December 1999 and March 2000) the relative frequency of leaf size between 71 and $90 \mathrm{~cm}$ decreased and, in comparison with the same months of the prolonged hydrologic connection, the number of leaves of more than $90 \mathrm{~cm}$ was low.

During the hydrologic connection the nitrogen content of the mature leaves increased from March 1998 to August 1998 mainly at Site B (Table 3). The phosphorus concentration remained relatively constant at both sites during the sampling dates. The lignin content of green leaves fluctuated between 0.92 and $1.41 \%$ and the L:N ratio ranged from 0.36 to 0.71 (Table 3). Mature leaves growing during the hydrologic isolation had lower nitrogen content (between 1.29 and 2.02), more lignin content and higher L:N ratio than those plants collected during the prolonged connection at the same sites (Table 3).

\section{DISCUSSION}

Our results indicated that, E. crassipes growing in the lake more connected with the

TABLE 3

Nutrient content of green leaves at both sites during different hydrological conditions

\begin{tabular}{|c|c|c|c|c|c|c|c|c|c|c|c|c|}
\hline & \multicolumn{4}{|c|}{ Prolonged hydrologic connection } & \multicolumn{8}{|c|}{ Prolonged hydrologic isolation } \\
\hline & \multicolumn{2}{|c|}{ Site A } & \multicolumn{2}{|c|}{ Site B } & \multicolumn{4}{|c|}{ Site A } & \multicolumn{4}{|c|}{ Site B } \\
\hline & $\begin{array}{c}\text { Mar- } \\
98\end{array}$ & $\begin{array}{c}\text { Aug } \\
98\end{array}$ & $\begin{array}{c}\text { Mar } \\
98\end{array}$ & $\begin{array}{c}\text { Aug } \\
98\end{array}$ & $\begin{array}{c}\text { Aug } \\
99\end{array}$ & $\begin{array}{c}\text { Mar } \\
00\end{array}$ & $\begin{array}{c}\text { Apr } \\
00\end{array}$ & $\begin{array}{c}\text { Jul } \\
01\end{array}$ & $\begin{array}{c}\text { Aug } \\
99\end{array}$ & $\begin{array}{c}\text { Mar } \\
00\end{array}$ & $\begin{array}{c}\text { Apr } \\
00\end{array}$ & $\begin{array}{c}\text { Jul } \\
01\end{array}$ \\
\hline $\mathrm{N}(\%)$ & $\begin{array}{c}1.58 \\
\pm 0.03\end{array}$ & $\begin{array}{c}2.13 \\
\pm 0.05\end{array}$ & $\begin{array}{c}1.34 \\
\pm 0.01\end{array}$ & $\begin{array}{c}2.53 \\
\pm 0.03\end{array}$ & $\begin{array}{c}2.02 \\
\pm 0.005\end{array}$ & $\begin{array}{c}1.29 \\
\pm 0.17\end{array}$ & $\begin{array}{c}1.60 \\
\pm 0.045\end{array}$ & $\begin{array}{c}1.76 \\
\pm 0.25\end{array}$ & $\begin{array}{c}2.08 \\
\pm 0.035\end{array}$ & $\begin{array}{c}1.32 \\
\pm 0.15\end{array}$ & $\begin{array}{c}1.89 \\
\pm 0.08\end{array}$ & $\begin{array}{c}2.11 \\
\pm 0.04\end{array}$ \\
\hline $\mathrm{P}(\%)$ & $\begin{array}{c}0.27 \\
\pm 0.003\end{array}$ & $\begin{array}{c}0.35 \\
\pm 0.02\end{array}$ & $\begin{array}{c}0.24 \\
\pm 0.02\end{array}$ & $\begin{array}{c}0.23 \\
\pm 0.00\end{array}$ & $\begin{array}{l}0.193 \\
\pm 0.01\end{array}$ & $\begin{array}{c}0.20 \\
\pm 0.01\end{array}$ & $\begin{array}{c}0.23 \\
\pm 0.015\end{array}$ & $\begin{array}{c}0.25 \\
\pm 0.01\end{array}$ & $\begin{array}{c}0.16 \\
\pm 0.01\end{array}$ & $\begin{array}{c}0.19 \\
\pm 0.02\end{array}$ & $\begin{array}{c}0.27 \\
\pm 0.02\end{array}$ & $\begin{array}{c}0.34 \\
\pm 0.02\end{array}$ \\
\hline Lignin $(\%)$ & $\begin{array}{c}1.04 \\
\pm 0.12\end{array}$ & $\begin{array}{c}1.41 \\
\pm 0.33\end{array}$ & $\begin{array}{c}0.96 \\
\pm 0.06\end{array}$ & $\begin{array}{c}0.92 \\
\pm 0.05\end{array}$ & $\begin{array}{r}4.57 \\
\pm 1.06\end{array}$ & $\begin{array}{c}3.99 \\
\pm 0.37\end{array}$ & $\begin{array}{c}5.80 \\
\pm 0.30\end{array}$ & $\begin{array}{c}3.60 \\
\pm 0.42\end{array}$ & $\begin{array}{c}5.26 \\
\pm 0.96\end{array}$ & $\begin{array}{c}3.98 \\
\pm 0.64\end{array}$ & $\begin{array}{c}5.57 \\
\pm 1.11\end{array}$ & $\begin{array}{c}3.90 \\
\pm 0.07\end{array}$ \\
\hline $\mathrm{L}: \mathrm{N}$ & 0.65 & 0.66 & 0.71 & 0.36 & 2.26 & 3.09 & 3.62 & 2.04 & 2.53 & 3.01 & 2.94 & 1.84 \\
\hline
\end{tabular}


Prolonged hydrological conection
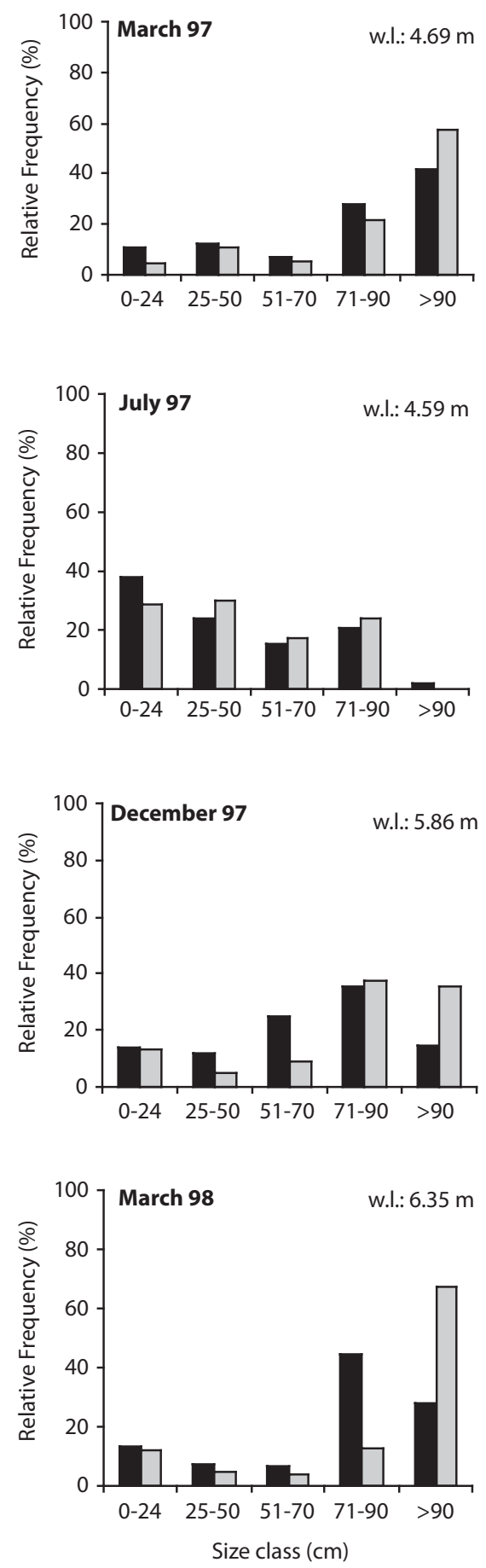

Prolonged hydrologic isolation
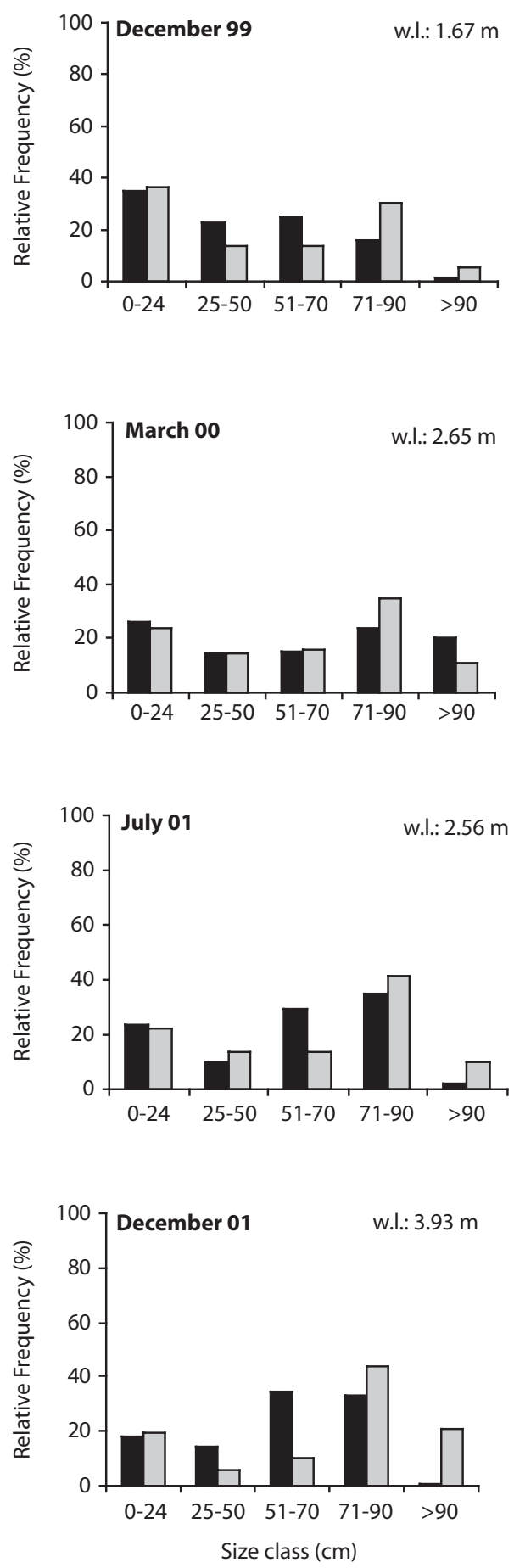

Fig. 3. Relative frequency of size class of green leaves at site A (dark bars) and site B (light bars). w.l: water level of Paraná River in the Corrientes gauge. 
Paraná River had longer leaves and less root biomass than those found in the lake more isolated. Due to the differences in leaf density between floodplain lakes, we were unable to demonstrate the effect of connectivity on leaf size when prolonged hydrologic connection and prolonged hydrologic isolation were analyzed together. However, the lakes don't present differences in leaf density and, the height of the leaves respond to hydrologic connectivity when the prolonged hydrologic connection is considered alone, as was demonstrated by Neiff et al. (2001).

Differences in leaf height and, leaf and root biomasses between prolonged hydrologic connection and prolonged hydrologic isolation in each floodplain lakes showed that these morphological variables and the ratio between below-ground and above-ground biomasses respond to pluri-annual water level fluctuation. The not significant relationship between leaf size and leaf density between different hydrologic conditions indicated that differences in leaf height (thus leaf biomass) are not related to differences in leaf density.

Given that during the floods the $\mathrm{NO}_{3}$ appearing in the Paraná River floodplain lakes had a riverine origin, our results suggest that E. crassipes respond to the influx of nitrogen during the prolonged hydrologic connection. Experimental studies showed that plants partition more biomass to above ground part when E. crassipes is exposed to a growth medium where the nitrogen availability is gradually increasing (Xie et al. 2004).

In other floodplain lakes the maximum biomass of the large biotype of E. crassipes was registered during the filling phase, but the subsequent reduction occurred during the low water phase, was a result of thermal stress from low temperatures (Da Silva and Esteves 1993). The biomass of other free floating plant (Salvinia auriculata) was not affected by fluctuations in the water level (Bini 1996). The maximum biomass for plants of the large biotype, about $40 \mathrm{~cm}$ in length, in the floodplain of the Cuiaba River (Da Silva and Esteves 1993) was lower $\left(600 \mathrm{~g}\right.$ dry weight $\left.\mathrm{m}^{2}\right)$ than the value of the present study (1 $630 \mathrm{~g}$ dry weight $\mathrm{m}^{2}$ ).
At both floodplain lakes total biomass per surface area exhibited similar changes at prolonged hydrologic connection and prolonged hydrologic isolation. However, the highest values were registered in the lake more connected to the Paraná River. Our results suggest that the inflow of floods during winter does not appear to stimulate the increases of longest leaves and highest biomass. The low temperature and the damage by herbivores that accelerate the winter decay of $E$. crassipes affect the biomass in these floodplain lakes (Poi de Neiff and Casco 2003).

According to Wilson et al. (2005), the relationship between plant growth and plant nitrogen and, between plant growth and water nitrogen imply a relationship between water nitrogen and plant nitrogen. Our study show that under natural nutrient supply, nutrient concentration in mature leaves at the lake more connected was close to the maximum values measured by Carignan et al. (1994) in enclosures treated with nitrogen during 30 days $(\mathrm{TN}=2.58 \%)$. However our value was found only at the end of the prolonged hydrologic connection (468 days) after the inflow of four river pulses. During the prolonged isolation the nitrogen content of the mature leaves was in the range found by Carignan et al. (1994) in different floodplain lakes during low water condition. Low supplies of nitrogen result in decreasing of plant height and fibrous plants with lower nitrogen and higher lignin content (Tucker 1981) as we registered at Site A. During the prolonged drought phosphorus content of green leaves was close to the critical phosphorus requirement reported by Gerloff (1970) for submersed aquatic plants.

Due to the indirect and diffuse hydrologic connections of the floodplain lakes with the Paraná River we were unable to measure the fluxes of nutrients in each lake. However, the effect of floods on lakes fertilization can be shown by the relating changes in plants vigour to nutrient influxes from the river in representative water bodies during representative floods. The response of the plants to water level fluctuations (thus inflow of nitrogen) depends on 
the amplitude of the phase in each pulse and the location of the lakes along the geomorphologic gradient indicated by the FCQ.

The present study only considers floating meadows that growth in the absence of interspecific competitors in natural floodplain lakes with high cover and dominance of the large biotype. The success of E. crassipes in occupy this habitat, subjected to wide and erratic fluctuations in water level, appears to be related to its ability to modify the morphological traits according to the availability of nutrients in water.

\section{ACKNOWLEDGMENTS}

We thank Richard Carignan and Luiz Mauricio Bini for thoughtful reviews of the manuscript and for constructive suggestions for its improvement. We are grateful to A. Ramos and J. Cáceres for technical assistance with nutrient determinations in water. The chemical analysis of leaves was made by the Argentine Catholic University. This is a contribution by the PICT 12755 project ANPCYT (FONCYT) and PIP 6316 project (CONICET). We thank Indiana Basterra Chiozzi for providing the CONAE satellite images.

\section{RESUMEN}

Se analiza la respuesta de Eichhornia crassipes, una de las plantas acuáticas más frecuentes en la planicie de inundación del río Paraná, a las fluctuaciones del río en dos lagos con diferente conectividad. Las muestras fueron tomadas en 13 condiciones hidrológicas entre Marzo de 1997 y Diciembre de 2001. Durante el periodo de prolongada conectividad hidrológica, el área cubierta por el agua aumenta más de tres veces y el contenido de nitrógeno inorgánico disuelto fue mayor en comparación con la condición de prolongado aislamiento. En comparación con las plantas del lago más aislado del río, las del más conectado tuvieron significativamente menor densidad de hojas, hojas más largas, menor biomasa de raíces y menor cociente entre la biomasa de las partes aéreas y las partes sumergidas. Las diferencias en la altura y la biomasa de hojas y raíces entre diferentes condiciones hidrológicas y la no significativa relación entre el tamaño y su densidad, indican que las características morfológicas de las plantas responden a fluctuaciones del nivel del agua. Durante la prolongada conexión con el río el contenido de nutrientes de las hojas maduras fue alto, en tanto que durante el aislamiento pro- longado las hojas tuvieron mayor contenido de lignina y alto cociente L:N. El éxito de Eichhornia crassipes en la ocupación de hábitats sujetos a amplias y erráticas fluctuaciones del nivel del agua parece estar relacionado con su capacidad para modificar sus características morfológicas en función de las fluctuaciones del nivel del agua.

Palabras clave: grandes ríos, Eichhornia crassipes, pulsos, planicies inundables.

\section{REFERENCES}

APHA (American Public Health Association). 1999. Standard Methods for the Examination of Water and Wastewater $20^{\text {th }}$ edition. American Public Health Association, Washington DC, USA.

Ashton, H.I. 1973. Aquatic Plant of Australia, Melbourne University. Melbourne, Victoria, Australia.

AOAC (Association of Official Analytical Chemists). 1990. Phosphorus in Animal feed, photometric methods. Association of Official Analytical Chemists, Arlington, Vancouver, USA.

Bini, L.M. 1996. Influência do pulso de inundação nos valores de fitomassa de três espécies de macrófitas aquáticas. Arq. Biol. Tecnol. 39: 715-721.

Blanco, L., J.J. Neiff \& A.S. Poi de Neiff. 1998. Invertebrate fauna associated with floating macrophytes in the floodplain lakes of the Orinoco (Venezuela) and Paraná (Argentina). Verh. Internat. Verein. Limnol. 26: 2030-2034.

Carignan, R. \& J.J. Neiff. 1992. Nutrient dynamics in the floodplain ponds of the Paraná river (Argentina) dominated by the water hyacinth Eichhornia crassipes. Biogeochemistry 17: 85-121.

Carignan, R., J.J. Neiff \& D. Planas. 1994. Limitation of water hyacinth by nitrogen in subtropical lakes of the Paraná floodplain (Argentina). Limnol. Oceanogr. 39: 439-443.

Center, T.D. \& N.H. Spencer. 1981. The phenoly and growth of water hyacinth (Eichhornia crassipes) in an eutrophic north-central Florida lake. Aquat. Bot. 10: 1-32.

Colonnello, G. 1995. La vegetación acuática del Delta del Río Orinoco (Venezuela). Composición florística y aspectos ecológicos (I). Mem. Soc. Cienc. Nat. La Salle 144: 3-34.

Da Silva, C. \& F.A. Esteves. 1993. Biomass of three macrophytes in the Pantanal of the Mato Grosso, Brazil. Int. J. Ecol. Environ. Sci. 19: 11-23. 
Downing, J.A. \& M.R. Anderson. 1985. Estimating the standing biomass of aquatic macrophytes. Can. J. Fish Aquat. Sci. 42: 1860-1869.

Gerloff, C.G. 1970. Evaluating nutrient supplies for the growth of aquatic plants in natural waters, p. 537-555. In Anonymous (ed.). Symposium Proceedings, National Academy of Sciences, Eutrophication, causes, consequences and correctives, Washington DC, USA.

InfoStat. 2002. InfoStat, version 1.1. Manual del usuario. Grupo InfoStat, FCA, Universidad Nacional de Córdoba. Brujas, Córdoba, Argentina.

Navarro, G. \& M. Maldonado. 2002. Geografía Ecológica de Bolivia: vegetación y ambientes acuáticos. Fundación Simón Patiño, Cochabamba, Cochabamba, Bolivia.

Neiff, J.J. 1986. Aquatic macrophytes of Paraná River, p. 557-571. In K.F Walker \& B.R. Davies (eds.). The Ecology of River Systems. Dr. Junk. Dordrecht, South Holland, The Netherlands.

Neiff, J.J. 1996. Large rivers of South America: toward the new approach. Verh. Internat. Verein. Limnol. 26: $167-180$.

Neiff, J.J. 2001. Diversity in some tropical wetland systems of South America, p. 157-186. In B. Gopal, W.J. Junk \& J.A. Davis (eds.). Biodiversity in wetlands: assessment, function and conservation. Backhuys, Leiden, South Holland, The Netherlands.

Neiff, J.J. \& A. Poi de Neiff. 1984. Cambios estacionales en la biomasa de Eichhornia crassipes y su fauna en una laguna del Chaco. Ecosur 11: 51-60.

Neiff, J. J. \& A. Poi de Neiff. 2003. Connectivity processes as a basis for the management of aquatic plants, p. 39-58. In S.M. Thomaz \& L.M. Bini (eds.). Ecologia e Manejo de Macrófitas Aquáticas. Eduem, Maringá, Paraná, Brazil.

Neiff, J.J., M.H. Iriondo \& R. Carignan. 1994. Large Tropical South American Wetlands: An Overview, p.156-165. In Anonymous (ed.). Proceedings of the Internat. Workshop on the Ecology and Management of Aquatic-Terrestrial Ecotones, Washington DC, USA.

Neiff, J.J., A. Poi de Neiff \& S.L. Casco. 2001. The effect of prolonged floods on Eichhornia crassipes growth in the Paraná River floodplain lakes. Acta Limnol. Bras. 13: 51-60.
Poi de Neiff, A. \& S.L. Casco. 2003. Biological agents which accelerate winter decay of aquatic plants in the Northeast of Argentina, p 127-144. In S. Magela Thomaz \& L.M. Bini (eds.). Ecologia e Manejo de Macrófitas Aquáticas. Universidade Estadual de Maringá, Paraná, Brazil.

Pompêo, M.L.M. \& V. Moschini-Carlos. 2003. Macrófitas aquáticas e perifíton, aspectos ecológicos e metodológicos. RiMa, San Carlos, San Pablo, Brazil.

Puhakka, M. \& R. Kalliola. 1993. La vegetación en áreas de inundación en la selva baja de la Amazonia, p 113-138. In R. Kalliola, M. Puhakka \& W. Danjoy (eds.). Amazonia Peruana. PAUT y ONERN, Jyväskylä, Finland.

Rodriguez, J.C. \& J.A. Betancourt. 1999. Caracterización físico-química de una laguna de inundación del tramo Orinoco medio y su relación con la biomasa de la cobertura de bora (Eichhornia crassipes (Mart.). Solms). Interciencia 24: 243-250.

Sahai, R. \& A.B. Sinha. 1970. Contribution to the Ecology of Indian Aquatics. Hydrobiologia 3-4: 376-382.

Thomaz, S.M., T.A. Pagioro, L.M Bini, M.C. Roberto \& R. Ribeiro. 2004. Limnological characterization of the aquatic environments and the influence of hydrometric levels, p. 75-102. In S.M. Thomaz, A.A. Agostinho \& N.S. Hahn (eds.). The Upper Paraná River and its Floodplain, physical aspects, ecology and conservation. Backhuys, Leiden, South Holland, The Netherlands.

Tucker, C.S. 1981. The effect of ionic form and level of nitrogen on the growth and composition of Eichhornia crassipes. Hydrobiologia 83: 517-522.

Wilson, J.R., H. Niels \& M. Rees. 2005. Determinants and patterns of population growth in wateryacynth. Aquat. Bot. 81: 51-67.

Xie, Y., M. Wen, D. Yu \& Y. Li. 2004. Growth and resource allocation of water hyacinth as affected by gradually increasing nutrient concentrations. Aquat. Bot.79: 257-266.

\section{INTERNET REFERENCES}

Neiff, J.J. \& M. Neiff. 2003. PULSO, software para análisis de fenómenos recurrentes. Dir. Nac. de Derecho de Autor $N^{\circ}$ 236164, 17 de febrero, Buenos Aires, Argentina (downloaded October 13, 2007, http:// www.neiff.com.ar) 